\title{
RADIOCARBON DATES FROM SOIL PROFILES IN THE TEOTIHUACÁN VALLEY, MEXICO: INDICATORS OF GEOMORPHOLOGICAL PROCESSES
}

\author{
Emily McClung de Tapia ${ }^{1}$ Irma Domínguez Rubio ${ }^{2}$ Jorge Gama Castro ${ }^{3}$ Elizabeth Solleiro ${ }^{3}$ \\ Sergey Sedov ${ }^{3}$
}

\begin{abstract}
Radiocarbon dates largely obtained from bulk soil samples in 24 soil profiles in the Teotihuacán Valley, Mexico, are reported insofar as they represent a first step towards developing a sequence of soil formation, erosion, vegetation change, and human impact during the Holocene. Limitations of ${ }^{14} \mathrm{C}$ dating in the area are considered, particularly the absence of charcoal in sediments and poor preservation of pollen. A broad temporal scheme is proposed to guide future research in which 4 periods are defined: 5000-2000 BP (relative stability with short, intermittent episodes of erosion); 2000-1500 BP (erosion-sedimentation, deforestation, and intensive agriculture); 1500-1000 BP (relative stability, depopulation, and partial recovery of the landscape); and $\sim 1000-500 \mathrm{BP}$ (erosion-sedimentation, deforestation, and intensive agriculture).
\end{abstract}

\section{INTRODUCTION}

Between 1992 and 1999, 24 soil profiles were excavated in the Teotihuacán Valley, State of Mexico (Figure 1), in order to study the formation of soils, erosion, and human impact associated with prehispanic settlement, resource extraction, and production in the region. The region, located approximately $50 \mathrm{~km} \mathrm{NE}$ of Mexico City, is best known for the archaeological site of Teotihuacán, the earliest city of its size and density in the Americas, occupied between approximately AD 1-650. Although the prehispanic urban center of Teotihuacán represents a significant focus for our research, our initial goal was to establish a broad outline of the sequence of landscape transformation throughout the Holocene, based on the analysis of sediments and associated plant remains, including macrobotanical remains, pollen, and phytoliths (McClung de Tapia et al. 2003).

In the Teotihuacán Valley, only very limited paleoenvironmental research had been undertaken prior to our investigation, including geological surveys reported by Mooser (1968) and Barba (1995), a palynological study by Kovar (1970), and an analysis of Aztec and Colonial period landscape change in the Texcoco region, which included a portion of the southern extreme of the Teotihuacán Valley (Cordova 1997). Only Cordova's research incorporated radiocarbon determinations of organic materials recovered from profiles. Consequently, our analysis represents the first stage of an attempt to develop a sequence of regional landscape dynamics in the area during the Holocene.

Paleoenvironmental studies of lake sediments reported from other sectors of the Basin of Mexico indicate relatively dry conditions during the Late Glacial continuing into the Early Holocene (Lozano-García and Ortega-Guerrero 1998; Caballero et al. 1999). Palynological studies of cores from lakes Texcoco and Chalco (Lozano-García et al. 1993; Lozano García and Ortega-Guerrero 1998) $\mathrm{S}$ and $\mathrm{E}$ of the Teotihuacán Valley, respectively, and Lake Tecocomulco in the NE (Caballero et al. 1999), consistently reveal evidence for human impact during the Middle-Late Holocene that obscures possible indicators of episodes of climatic-induced vegetation change or other evidence for climatic variability that could have affected human settlements in prehispanic times.

\footnotetext{
${ }^{1}$ Laboratorio de Paleoetnobotánica y Paleoambiente, Instituto de Investigaciones Antropológicas, Universidad Nacional Autónoma de México. Corresponding author. Email: mcclung@servidor.unam.mx.

${ }^{2}$ Deceased. Departamento del Hombre y su Medio Ambiente, Universidad Autónoma Metropolitana-Xochimilco.

${ }^{3}$ Departamento de Edafología, Instituto de Geología, Universidad Nacional Autónoma de México.
} 


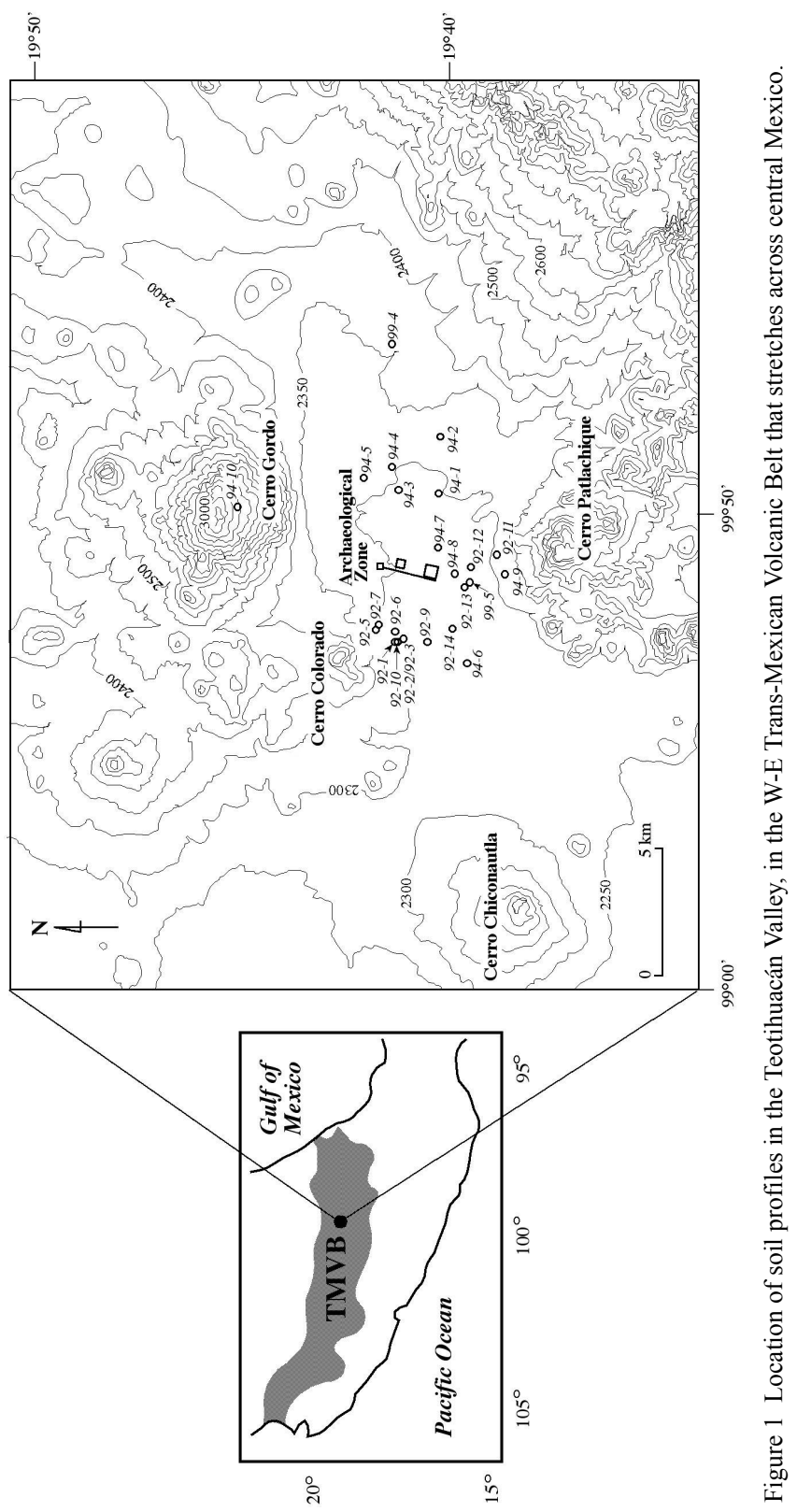




\section{METHODOLOGY}

Initially, a N-SE transect between Cerro Colorado and Cerro Patlachique was studied, followed by additional profiles in the alluvial plain $\mathrm{S}$ and $\mathrm{E}$ of the ancient city and on Cerro Gordo to the $\mathrm{N}$. An attempt was made to locate soil profiles at or beyond the margins of the ancient city in order to evaluate soil variability and its relationship to human occupation. However, buried remains of prehispanic structures were encountered occasionally.

${ }^{14} \mathrm{C}$ dates on bulk sediment were obtained from the upper $5 \mathrm{~cm}$ of selected horizons in order to relate formation processes and erosive sequences in different sectors of the valley and to contribute to an understanding of vegetation change over time as indicated by grass phytoliths recovered from dated horizons. Unfortunately, pollen is poorly preserved in the region and in situ pollen materials were insufficient for dating. Both pollen and phytoliths were also subject to redeposition in the alluvial plain. All samples were pretreated by Beta Analytic, Inc, Miami, Florida, USA. Pretreatment consisted of the removal of any apparent roots, followed by mechanical dispersion in hot acid (HCL) to eliminate carbonates. Samples were subsequently rinsed repeatedly until neutralized, then dried and subjected to combustion in an enclosed system. Conventional dates were obtained by benzene synthesis and counting at the Beta Analytic facility. Accelerator mass spectrometry (AMS) measurements based on sample carbon reduced to graphite (processed by Beta Analytic) were undertaken at Lawrence Livermore National Laboratory. The results represent the total organic content of the analyzed material and ${ }^{14} \mathrm{C}$ determinations are interpreted to reflect mean residence time (MRT) of organic carbon in the soil (SOM) unless otherwise indicated. Visible in situ charcoal was absent from all strata, with the unique exception of a fragment of maize stem (Zea mays L.) recovered from profile 92-14. The charcoal, dated by AMS (Beta-60633), was soaked in hot alkalai to remove humic acids, followed by rinsing to neutrality, then an acid wash as described above, and another rinsing to neutrality.

The following types of layers were dated: Ah horizons of well-developed buried paleosols with normal A-B-C horizon sequences and primarily in situ humus formation; sedimentary sequences consisting of several superimposed A and AC horizons, both of which contain in situ organic material; and $\mathrm{C}$ horizons with sufficient organic carbon. Sometimes, humus-enriched B horizons were sampled because, during field survey, they were first described as A horizons, and relabeled after laboratory results were available.

Because of the relatively large number of dates (79) and their potential significance for establishing stratigraphic relations, this report is organized by zones and associated profiles. Two principal zones are recognized - uplands and the alluvial plain - within which the location of each profile is briefly described, followed by dates and a brief reference to the other horizons. In addition, when profiles are located within the urban area of Teotihuacán, references are included to the 1:2000 map sheets of the Teotihuacán map (Millon et al. 1973); otherwise, profiles are situated with respect to the 1:50,000 Texcoco map (E14B21, INEGI 1983). All samples were submitted to Beta Analytic by Emily McClung de Tapia. ${ }^{14} \mathrm{C}$ determinations are reported as conventional ${ }^{14} \mathrm{C}$ yr before $\mathrm{AD} 1950$, with standard errors as provided by the laboratory. Because we feel that calibrations BC/AD do not contribute significantly to the interpretation of the data, these are only included in Table 1, where specific ${ }^{14} \mathrm{C}$ dates obtained from sediments are compared to associated cultural remains. Calibrations were calculated using CALIB rev 4.3 (Stuiver and Reimer 1993). $\delta^{13} \mathrm{C}$ values are not considered in detail at this time since additional research is underway in the region to establish their significance, particularly in chronological terms. 
Table 1 Horizons or archaeological strata with associated cultural evidence. Calibrations were calculated in Calib rev 4.3 (Stuiver and Reimer 1993).

\begin{tabular}{|c|c|c|c|c|c|c|}
\hline Profile/Depth & Horizon & Zone & $\begin{array}{l}\text { Lab \# } \\
\text { (Beta-) }\end{array}$ & $\begin{array}{l}{ }^{14} \mathrm{C} \\
\text { determination }\end{array}$ & $\mathrm{Cal} \mathrm{BC} / \mathrm{AD}$ & Cultural context \\
\hline $92-1(60-72 \mathrm{~cm})$ & $2 \mathrm{~A}_{1}$ & Upland & 68355 & $5520 \pm 110$ & cal BC $4580-4050$ & $\begin{array}{l}\text { Sediment underlying } \\
\text { Teotihuacán structure }\end{array}$ \\
\hline $92-2(44-54 \mathrm{~cm})$ & $2 \mathrm{~A}$ & Upland & 68332 & $3600 \pm 80$ & cal BC $2200-1740$ & $\begin{array}{l}\text { Sediment underlying } \\
\text { Teotihuacán burial }\end{array}$ \\
\hline $92-14(1.10-1.17 \mathrm{~cm})$ & $2 \mathrm{~B}$ & Alluvial plain & 60633 & $\begin{array}{l}490 \pm 60 \\
(\mathrm{AMS})\end{array}$ & cal AD $1320-1490$ & $\begin{array}{l}\text { Carbonized maize } \\
\text { stalk }\end{array}$ \\
\hline $92-13(61-167 \mathrm{~cm})$ & n.d. & Alluvial plain & 68358 & $2690 \pm 70$ & cal BC $1000-790$ & $\begin{array}{l}\text { Sediment underlying } \\
\text { foundation of } \\
\text { Teotihuacán structure }\end{array}$ \\
\hline $99-5(95-120 \mathrm{~cm})$ & $\mathrm{B}_{2}$ & Alluvial plain & 142228 & $2890 \pm 50$ & cal BC 1260-920 & $\begin{array}{l}\text { Classic } \\
\text { Teotihuacán ceramics }\end{array}$ \\
\hline $99-5(120-133 \mathrm{~cm})$ & $\mathrm{C}$ & Alluvial plain & 142229 & $3370 \pm 60$ & cal BC $1870-1520$ & $\begin{array}{l}\text { Classic } \\
\text { Teotihuacán ceramics }\end{array}$ \\
\hline $99-5(133-158 \mathrm{~cm})$ & $2 \mathrm{~A}_{11}$ & Alluvial plain & 142230 & $2990 \pm 80$ & cal BC 1430-980 & $\begin{array}{l}\text { Classic } \\
\text { Teotihuacán ceramics }\end{array}$ \\
\hline $99-5(158-171 \mathrm{~cm})$ & $2 \mathrm{~A}_{12}$ & Alluvial plain & 142231 & $3110 \pm 80$ & cal BC $1520-1130$ & $\begin{array}{l}\text { Classic } \\
\text { Teotihuacán ceramics }\end{array}$ \\
\hline $99-4(\mathrm{~N} 86-110 \mathrm{~cm})$ & $2 \mathrm{~A}_{11}$ & Alluvial plain & 142223 & $2890 \pm 60$ & cal BC 1290-900 & $\begin{array}{l}\text { Predominantly } \\
\text { Mazapan-phase ce- } \\
\text { ramics (Aztec ceram- } \\
\text { ics in upper strata) }\end{array}$ \\
\hline
\end{tabular}

\section{RESULTS}

\section{Zone 1. Uplands}

\section{Cerro Colorado. Defensa Nacional (37a Zona Militar)}

The profiles described were located on the southeastern flank of Cerro Colorado, at the northwestern limit of the Archaeological Zone of Teotihuacán, San Juan Teotihuacán, State of Mexico. All samples consist of bulk sediment from the upper $5 \mathrm{~cm}$ of selected horizons. Descriptions of associated archaeological contexts are as yet unpublished, with the exception of 22:N1W6 (Cid 1998).

92-1. Located next to the visible remains of Structure $22\left(19^{\circ} 41^{\prime} 25^{\prime \prime} \mathrm{N}, 98^{\circ} 52^{\prime} 17^{\prime \prime} \mathrm{W}\right)$, at an elevation of $2350 \mathrm{~m}$ (Teotihuacán map, square NIW6, Millon et al. 1973:70). The dated horizon consists of a buried soil underlying a Classic period Teotihuacán structure (predominantly Tlamimilolpa-phase ceramics, Cid 1998:319). The polycyclic profile is represented by 3 superimposed soils that vary in morphology and age.

$$
\begin{aligned}
& \text { Ap }(0-30 \mathrm{~cm}) \\
& \mathrm{C}(30-60 \mathrm{~A} \mathrm{~cm}) \\
& 2 \mathrm{~A}_{11}(30-60 \mathrm{~B} \mathrm{~cm})
\end{aligned}
$$

$\begin{array}{lll}\text { Beta-68355 } & 2 \mathrm{~A}_{12}(60-72 \mathrm{~cm}) \text { underlying structure } 22 & 5520 \pm 110\end{array}$

$$
3 \mathrm{C}(>72 \mathrm{~cm})
$$

92-2. Located $50 \mathrm{~m}$ south of a road $\left(19^{\circ} 41^{\prime} 24.6^{\prime \prime} \mathrm{N}, 98^{\circ} 52^{\prime} 15^{\prime \prime} \mathrm{W}\right)$, at an elevation of $2282 \mathrm{~m}$, at the SW corner of Structure 16 (NIW5, Millon et al. 1973:71). The dated horizon consists of a buried soil underlying a Classic period multiple burial. The polycyclic profile is represented by 2 soils. The lim- 
ited development and depth of horizon 2A suggests that it formed during a short cycle of landscape stability.

$$
\begin{aligned}
& \text { Ao }(0-4 \mathrm{~cm}) \\
& \text { A }(4-44 \mathrm{~cm})
\end{aligned}
$$

Beta-68332 2A (44-54 cm) underlying Classic period multiple burial $\quad 3600 \pm 80$ $2 \mathrm{C}(>54 \mathrm{~cm})$

92-3. Located $50 \mathrm{~m} \mathrm{~W}$ of Structure 22, NIW6, $\left(19^{\circ} 41^{\prime} 24.6^{\prime \prime} \mathrm{N}, 98^{\circ} 52^{\prime} 15^{\prime \prime} \mathrm{W}\right)$, on the southeastern flank of Cerro Colorado, at an elevation of $2282 \mathrm{~m}$ (NIW6, Millon et al. 1973:70). The origin, morphology, and properties of this profile are similar to $92-2$. Beta- 68357 from the underlying horizon $(>52 \mathrm{~cm})$ provided insufficient carbon for dating.

$\begin{array}{llr} & \text { A }(0-19 / 32 \mathrm{~cm}) & \\ \text { Beta-68356 } & 2 \mathrm{~A}(32-52 \mathrm{~cm}) & 2850 \pm 70 \\ & 2 \mathrm{C}(>52 \mathrm{~cm}) & \end{array}$

92-5. Represents the wall of a zanja (ditch), $10 \mathrm{~m}$ E of Structure $13\left(19^{\circ} 41^{\prime} 56^{\prime \prime} \mathrm{N}, 98^{\circ} 51^{\prime} 56^{\prime \prime} \mathrm{W}\right)$, on the southeastern flank of Cerro Colorado, at an elevation of $2306 \mathrm{~m}$ (N4W5, Millon et al. 1973: 26). This polycyclic profile is highly stratified, and comprised of 4 poorly developed soils derived from colluvium-alluvium. The dated horizons correspond to the second soil below the surface. Beta-68334 (3C, 64-94 cm) and Beta-68335 (4C, $>94 \mathrm{~cm})$ provided insufficient carbon for dating.

$\begin{array}{lll} & \mathrm{AC}(0-14 \mathrm{~cm}) & \\ \text { Beta- } 68333 & 2 \mathrm{AC}_{1}(14-30 \mathrm{~cm}) & \\ & 2 \mathrm{AC}_{2}(30-40 \mathrm{~cm}) & \\ \text { Beta-60626 } & 2 \mathrm{C}(40-64 \mathrm{~cm}) & \\ & 3 \mathrm{C}(64-90 \mathrm{~cm}) & \\ & 4 \mathrm{C}(>94 \mathrm{~cm}) & \end{array}$

92-6. Wall of a jaguey (seasonal water deposit) $\left(19^{\circ} 41^{\prime} 30.6^{\prime \prime} \mathrm{N}, 98^{\circ} 52^{\prime} 04^{\prime \prime} \mathrm{W}\right.$ ), at $2285 \mathrm{~m}$ (north face of a leveled mound designated as Site 12:N1W5, Millon et al. 1973:71). Dated horizons $\mathrm{A}_{1}, \mathrm{~A}_{2}$, and $\mathrm{A}_{3}$ represent a single pedological cycle of considerable depth, although poorly developed, overlying a $2 \mathrm{C}$ horizon formed in situ from tuff.

$\begin{array}{llc}\text { Beta-68342 } & \mathrm{A}_{1}(0-28 \mathrm{~cm}) & 101.3 \pm 0.9 \% \text { Modern } \\ \text { Beta-68343 } & \mathrm{A}_{2}(28-47 \mathrm{~cm}) & 970 \pm 80 \\ \text { Beta-68344 } & \mathrm{A}_{3}(47-69 \mathrm{~cm}) & 1690 \pm 60 \\ & \mathrm{C}(69-81 \mathrm{~cm}) & \\ \text { Beta-68345 } & 2 \mathrm{C}(81-101 \mathrm{~cm}) & 2120 \pm 70 \\ & \text { Tuff }(>101 \mathrm{~cm}) & \end{array}$

92-7. Located on a terraza (terrace) $40 \mathrm{~m} \mathrm{~W}$ of Structure $19\left(19^{\circ} 41^{\prime} 59^{\prime \prime} \mathrm{N}, 98^{\circ} 52^{\prime} 02^{\prime \prime} \mathrm{W}\right)$, at an elevation of $2315 \mathrm{~m}$ (N4W6, Millon et al. 1973:25). The Ap horizon developed from modern sediment overlying the buried $2 \mathrm{C}$ horizon formed by weathering of the underlying tuff. Based on Mielich (1991) and Quantin (1992), Hidalgo (1996:46) refers to the succession of pyroclastic deposits (tuff, or tepetate as it is referred to locally) evident in the foothills and alluvial plain of the western slope of the Sierra Nevada, forming the following series: $\mathrm{T}_{1}<8000 \mathrm{BP}, \mathrm{T}_{2 \mathrm{a}}<13,000 \mathrm{BP}, \mathrm{T}_{2 \mathrm{~b}}<21,000 \mathrm{BP}$, $\mathrm{T}_{3}<21,000-35,000 / 40,000$ BP. According to Peña and Zebrowski (1992:18), an additional series of unknown origin $\left(\mathrm{T}_{\mathrm{i}}\right)$ underlies Holocene deposits in the Teotihuacán region. The basalt flow west of Otumba is dated to the same period as the $\mathrm{T}_{2 \mathrm{a}}$ series. They also report a date of 7390 for volcanic ash 
(sample P39-4) in the Texcoco region, south of the Patlachique range (Peña and Zebrowski 1992: 11). No additional information (laboratory identification and number, specific material analyzed, confidence interval, etc.) is provided, although horizon descriptions are available. The same authors (1992:19) refer to a date of 7950 from humus corresponding to a buried soil in the alluvial plain of Texcoco $(2250 \mathrm{~m})$, again with no additional provenience information with respect to the sample or the laboratory result. It has not been possible to trace this information, but the dates obtained from Beta- 68347 and Beta- 68348 suggest that the $T_{i}$ series in the eastern sector of the Teotihuacán Valley may be approximately contemporaneous with $\mathrm{T}_{1}$ south of the Patlachique Range.

$\begin{array}{lll}\text { Beta-68346 } & \text { Ap }(0-25 \mathrm{~cm}) & 300 \pm 60 \\ & \text { A }(25-68 \mathrm{~cm}) & \\ & \text { C }(68-90 \mathrm{~cm}) & 7200 \pm 110 \\ \text { Beta-68347 } & \text { 2C }(90-110 \mathrm{~cm}) & 7900 \pm 160 \\ \text { Beta-68348 } & \text { Tuff }(>110 \mathrm{~cm}) & \end{array}$

92-10. Located $20 \mathrm{~m} \mathrm{SE}$ of structure 12-S, $15 \mathrm{~m} \mathrm{~W}$ of Structure $13\left(19^{\circ} 41^{\prime} 31.8^{\prime \prime} \mathrm{N}, 98^{\circ} 52^{\prime} 13.8^{\prime \prime} \mathrm{W}\right)$, at an elevation of $2288 \mathrm{~m}$ (N2W6, Millon et al. 1973:53). The profile is polycyclic, morphologically similar to 92-6. Beta-68352 (Tuff, $>69 \mathrm{~cm}$ ) provided insufficient carbon for dating.

$\begin{array}{llc} & \text { Ap }(0-6 \mathrm{~cm}) & \\ \text { Beta-68351 } & \text { AC }(6-34 \mathrm{~cm}) & 920 \pm 80 \\ \text { Beta-68330 } & \text { 2A }(34-56 \mathrm{~cm}) & 2150 \pm 80 \\ \text { Beta-60628 } & \text { 2A }(34-56 \mathrm{~cm}) & 2160 \pm 90 \\ \text { Beta-68331 } & \text { 2A }(34-56 \mathrm{~cm}) & \\ \text { (CAMS-10441) } & \delta^{13} \mathrm{C}=-16.4 & \\ & 2 \mathrm{C}(56-69 \mathrm{~cm}) & \\ & \text { Tuff }>69 & \end{array}$

\section{Sierra de Patlachique}

92-11. Located in Baranquilla del Aguila, $800 \mathrm{~m} \mathrm{~S}$ of the railroad $\left(19^{\circ} 39^{\prime} 30.6^{\prime \prime} \mathrm{N}, 98^{\circ} 50^{\prime} 26.4^{\prime \prime} \mathrm{W}\right)$, at $2304 \mathrm{~m}$. A polycyclic profile comprised of a poorly developed soil on tuff is represented, overlain by a thin colluvial stratum in which the modern Ah horizon has developed. Beta- 68338 from the 4Bt $(>66 \mathrm{~cm})$ horizon contained insufficient carbon for conventional dating.

$\begin{array}{llc}\text { Beta-68336 } & \mathrm{Ap}(0-26 \mathrm{~cm}) & 380 \pm 70 \\ \text { Beta-60629 } & 2 \mathrm{AB}(36-48 \mathrm{~cm}) & 2370 \pm 70 \\ \text { Beta-68326 } & \text { 2AB }(36-48 \mathrm{~cm}) & 3850 \pm 90 \\ \text { Beta-68327 } & 2 \mathrm{AB}(36-48 \mathrm{~cm}) & 4120 \pm 60 \text { AMS } \\ \text { (CAMS-10439) } & \delta^{13} \mathrm{C}=-16.0 & \\ \text { Beta-68337 } & 3 \mathrm{Bt}(36 / 48-66 \mathrm{~cm}) & 4790 \pm 130 \\ & 4 \mathrm{Bt}(>66 \mathrm{~cm}) & \end{array}$

94-9. Located close to La Concepción, $800 \mathrm{~m} \mathrm{~S}$ of the railroad $\left(19^{\circ} 39^{\prime} 19.6^{\prime \prime} \mathrm{N}, 98^{\circ} 50^{\prime} 48.9^{\prime \prime} \mathrm{W}\right)$, at $2315 \mathrm{~m}$. This polycyclic profile is comprised of 4 soils considerably altered by intensive erosion.

$\begin{array}{llr} & \text { Ap }(0-27 \mathrm{~cm}) & \\ & \text { A }(27-36 \mathrm{~cm}) & 390 \pm 60 \\ \text { Beta-73332 } & \text { 2AB }(36-92 \mathrm{~cm}) & 2410 \pm 80 \\ \text { Beta-73333 } & \text { 2B }(92-146 \mathrm{~cm}) & 2850 \pm 80 \\ \text { Beta-73334 } & \text { 3AB }(146-200 \mathrm{~cm}) & 3440 \pm 70\end{array}$




\section{Cerro Gordo}

94-10. Located $50 \mathrm{~m} \mathrm{~N}$ of an access road to a microwave station, $500 \mathrm{~m}$ beyond Barranca Honda $\left(19^{\circ} 44^{\prime} 47^{\prime \prime} \mathrm{N}, 98^{\circ} 49^{\prime} 20.3^{\prime \prime} \mathrm{W}\right)$, at $2930 \mathrm{~m}$. A Holocene Ah horizon, which developed over older, clay-illuvial Luvisol horizons of Late Pleistocene origin, is evident.

$\begin{array}{llc} & \text { Ap }(0-34 \mathrm{~cm}) & \\ \text { Beta-73336 } & \text { 2Ah }(34-50 \mathrm{~cm}) & 5250 \pm 70 \\ \text { Beta-73337 } & 3 \mathrm{Bt}(50-90 \mathrm{~cm}) & 18,740 \pm 150 \\ \text { Beta-73338 } & \text { 4Bt }(90-143 \mathrm{~cm}) & 22,670 \pm 290\end{array}$

\section{Zone 2. Alluvial Plain}

This zone represents a NE (Otumba)-SW (San Juan Teotihuacán) gradient that includes the Aztec town of Otumba to the NE and the Teotihuacán Archaeological Zone in the central valley, as well as the upper drainage basin of the San Juan River. The soils in this zone are derived from lacustrine and fluvial sediments.

92-9. Located approximately $50 \mathrm{~m}$ south of a road, $200 \mathrm{~m} \mathrm{~W}$ of the parish church of San Juan Teotihuacán (19 40 $\left.55.2^{\prime \prime} \mathrm{N}, 98^{\circ} 52^{\prime} 21^{\prime \prime} \mathrm{W}\right)$, at an elevation of $2267 \mathrm{~m}$ (S1W5, Millon et al. 1973:88). The area is characterized by a high water table that was originally fed by springs prior to the proliferation of artesian wells north of the town of San Juan Teotihuacán. It represents an anthropic profile comprised of a single, apparently well-developed soil with an abnormal chronostratigraphic sequence in the upper part. Dates are unreliable with respect to geomorphic processes and soil formation because layers contain redeposited humus resulting from ancient (and historic) land use practices. This area was cultivated since prehispanic times up to approximately $50 \mathrm{yr}$ ago utilizing a technique similar to the chinampas of the southeastern Basin of Mexico (but based on drained fields instead of constructed parcels [McClung de Tapia 2000]) in which sediments were continually dredged from adjacent canals and placed on the surface to be planted in order to increase fertility. Furthermore, recent archaeological research in the immediate area $\mathrm{W}$ of the parish church in San Juan Teotihuacán indicated buried Aztec structures at a depth of 3.5-4.0 m below the present surface (Cabrera-Castro 2002).

$\begin{array}{lll} & \text { Ap }(0-18 \mathrm{~cm}) & \\ \text { Beta-68353 } & \text { 2Ah }(18-40 \mathrm{~cm}) & 1970 \pm 70 \\ & \text { 2AE }(40-60 \mathrm{~cm}) & \\ \text { Beta-60627 } & \text { 2BC }(60-80 \mathrm{~cm}) & \\ & \text { 3B }(80-103 \mathrm{~cm}) & \\ & \text { 3BC }(103-143 \mathrm{~cm}) & 2650 \pm 70\end{array}$

92-12. Tlajinga 1 is located approximately $200 \mathrm{~m} \mathrm{NW}$ of the railroad $\left(19^{\circ} 40^{\prime} 3.2^{\prime \prime} \mathrm{N}, 98^{\circ} 51^{\prime} 2.4^{\prime \prime} \mathrm{W}\right)$, at an elevation of $2278 \mathrm{~m}$, in the deep soil agricultural area at the southern margin of the ancient city of Teotihuacán (S3E1, Millon et al. 1973:115). This profile shows moderate development overlying a layer of tuff. Beta- 68350 from the tuff $(>93 \mathrm{~cm})$ contained insufficient carbon for dating.

$\begin{array}{llr} & \mathrm{A}(0-15 \mathrm{~cm}) & \\ \text { Beta-68349 } & \mathrm{AB}(15-30 \mathrm{~cm}) & 470 \pm 70 \\ & \mathrm{~B}_{1}(30-43 \mathrm{~cm}) & 1460 \pm 80 \\ \text { Beta-60630 } & \mathrm{B}_{2}(43-93 \mathrm{~cm}) & \end{array}$


92-13. Tlajinga 2 represents the remains of a Classic period apartment compound not visible on the surface, located $100 \mathrm{~m} \mathrm{~W}$ of $92-12\left(19^{\circ} 40^{\prime} 4.8^{\prime \prime} \mathrm{N}, 98^{\circ} 51^{\prime} 8.4^{\prime \prime} \mathrm{W}\right)$, at an elevation of $2279 \mathrm{~m}$ (S3E1, Millon et al. 1973:115). The ${ }^{14} \mathrm{C}$ determination was obtained from soil immediately underlying foundations of a Classic period Teotihuacán structure. No laboratory analyses were carried out for the dated horizon.

$\begin{array}{lll} & \text { Ap }(0-38 \mathrm{~cm}) & \\ & 2 \mathrm{C}(38-61 \mathrm{~cm}) & \\ & 61-167 \mathrm{~cm}(\text { prehispanic structure }) & \\ \text { Beta-68358 } & \text { 3AC }(167-221 \mathrm{~cm} \text {, below prehispanic structure }) & 2690 \pm 70\end{array}$

92-14. Located $350 \mathrm{~m}$ E of the road from San Lorenzo Tlalmimilolpa to San Juan Teotihuacán, approximately $1 \mathrm{~km} \mathrm{~S}$ of San Juan Teotihuacán $\left(19^{\circ} 40^{\prime} 25.2^{\prime \prime} \mathrm{N}, 98^{\circ} 52^{\prime} 1.2^{\prime \prime} \mathrm{W}\right)$, at $2267 \mathrm{~m}(\mathrm{~S} 2 \mathrm{~W} 4$, unsurveyed zone between S2W5 and S2W3, Millon et al. 1973:102-3). The area is an important agricultural zone situated in the deep soil plain. The polycyclic profile is comprised of 3 soils manifesting different degrees of evolution: 0-86 cm (poorly developed), 86-212 cm and 212 to $>291 \mathrm{~cm}$ (well developed). Beta-68341 $(3 \mathrm{C}>291 \mathrm{~cm})$ contained insufficient carbon for dating. Charcoal from the $2 \mathrm{~B}$ horizon $(86-132 \mathrm{~cm})$ was identified by $\mathrm{E}$ McClung de Tapia as a maize stem fragment, confirmed by the $\delta^{13} \mathrm{C}$ value $(-10.0)$.

$\begin{array}{llc}\text { Beta-68339 } & \text { Ap }(0-34 \mathrm{~cm}) & 113.6 \pm 0.9 \% \text { Modern } \\ \text { Beta-68328 } & \text { 2Ah }(34-47 \mathrm{~cm}) & 670 \pm 70 \\ \text { Beta-68329 } & \text { 2Ah }(34-47 \mathrm{~cm}) & 1080 \pm 60 \text { AMS } \\ (\text { CAMS-10440) } & \delta^{13} \mathrm{C}=-20.0 & \\ \text { Beta-60631 } & \text { 2Ah }(34-47 \mathrm{~cm}) & 2040 \pm 80 \\ & \text { 2AB }(47-86 \mathrm{~cm}) & \\ \text { Beta-60633 } & \text { 2B }(86-132 \mathrm{~cm}) . \text { Charcoal between } 1.10-1.17 \mathrm{~m}, & 490 \pm 60 \text { AMS } \\ (\text { CAMS-10415) } & \delta^{13} \mathrm{C}=-10.0 & \\ \text { Beta-60632 } & \text { 2B }(86-132 \mathrm{~cm}) & 2290 \pm 90 \\ & 3 \mathrm{Ah}(132-154 \mathrm{~cm}) & \\ \text { Beta-68340 } & 3 \mathrm{Bt} 1(154-212 \mathrm{~cm}) & \\ & 3 \mathrm{Bt} 2(212-266 \mathrm{~cm}) & \\ & 3 \mathrm{BtC}(266-291 \mathrm{~cm}) & \\ & 3 \mathrm{C}(>291 \mathrm{~cm}) & \end{array}$

94-6. Located $1.5 \mathrm{~km} \mathrm{~W}$ of the road between San Lorenzo Tlalmimilolpa and San Juan Teotihuacán, $500 \mathrm{~m}$ S of Río San Lorenzo (19 $40^{\prime} 8.5^{\prime \prime} \mathrm{N}, 98^{\circ} 52^{\prime} 49.8^{\prime \prime} \mathrm{W}$ ), at $2260 \mathrm{~m}$ (W of S4W5 outside of survey zone, Millon et al. 1973:122). This highly stratified profile is comprised of 4 poorly developed soils of alluvial origin. Depths vary from $120 \mathrm{~cm}$ (surface) to 46,24 , and $30 \mathrm{~cm}$. The depths of the three earliest suggest short periods of landscape stability.

$\begin{array}{lll} & \text { Ap }(0-8 \mathrm{~cm}) & \\ \text { Beta-73322 } & \text { Ap/AC }(8-32 / 54 \mathrm{~cm}) & 107.8 \pm 0.9 \% \text { Modern } \\ \text { Beta-73323 } & \mathrm{C}_{1}(32 / 54-62 \mathrm{~cm}) & 2990 \pm 90 \\ \text { Beta-73324 } & \mathrm{C}_{2}(62-90 \mathrm{~cm}) & 3300 \pm 120 \\ \text { Beta-73325 } & \mathrm{C}_{3}(90-120 \mathrm{~cm}) & 3280 \pm 110 \\ \text { Beta-73326 } & 2 \mathrm{C}(120-166 \mathrm{~cm}) & 3760 \pm 110 \\ \text { Beta-73327 } & 3 \mathrm{C}(166-190 \mathrm{~cm}) & 3640 \pm 80 \\ \text { Beta-73328 } & 4 \mathrm{C}_{1}(190-220 \mathrm{~cm}) & 4070 \pm 160\end{array}$


94-1. Located $100 \mathrm{~m} \mathrm{~N}$ of Capultitlan, $1.5 \mathrm{~km} \mathrm{~N}$ of the road leading from the federal highway to Oxtoticpac $\left(19^{\circ} 40^{\prime} 42^{\prime \prime} \mathrm{N}, 98^{\circ} 49^{\prime} 04^{\prime \prime} \mathrm{W}\right)$, at $2298 \mathrm{~m}$. This polycyclic profile is comprised of 3 poorly developed soils of alluvial origin. The dynamics of formation are similar to profile $94-6$. The $3 \mathrm{C}_{3}$ horizon may be approximately contemporaneous with the $\mathrm{T}_{2 \mathrm{a}}$ series in the western piedmont of the Sierra Nevada (Hidalgo 1996:46; Peña and Zebrowski 1992:14).

$\begin{array}{llc}\text { Beta-73304 } & \mathrm{Ap}(0-21 \mathrm{~cm}) & 570 \pm 70 \\ \text { Beta-73305 } & 2 \mathrm{AC}(21-55 \mathrm{~cm}) & 3640 \pm 70 \\ \text { Beta-73306 } & 3 \mathrm{C}_{1}(55-66 \mathrm{~cm}) & 4680 \pm 210 \\ & 3 \mathrm{C}_{2}(66-86 \mathrm{~cm}) & \\ \text { Beta-73307 } & 3 \mathrm{C}_{3}(86-114 \mathrm{~cm}), & 11,670 \pm 60 \mathrm{AMS} \\ \text { (CAMS-14618) } & \delta^{13} \mathrm{C}=-18.4 & \end{array}$

94-3. Located in Santa María Coatlan, $500 \mathrm{~m} \mathrm{~N}$ of a road from the highway to Deportivo Teotihuacán $\left(19^{\circ} 41^{\prime} 32.7^{\prime \prime} \mathrm{N}, 98^{\circ} 48^{\prime} 59^{\prime \prime} \mathrm{W}\right)$, at $2298 \mathrm{~m}$. This polycyclic profile is similar to profile $94-1$, although stratification is more apparent, in addition to evidence for hydric erosion.

$\begin{array}{llr} & \text { Ap }(0-29 \mathrm{~cm}) & 1070 \pm 70 \\ \text { Beta-73312 } & \text { AC }(29-63 / 73 \mathrm{~cm}) & \\ & 2 \mathrm{C}_{1}(63-73) & \\ & 2 \mathrm{C}_{2}(>73 \mathrm{~cm}) & \end{array}$

94-7. Located in San Sebastian Xolalpan, $250 \mathrm{~m}$ E of the main water tank, at the exit to the federal highway to Tulancingo $\left(19^{\circ} 40^{\prime} 42.2^{\prime \prime} \mathrm{N}, 98^{\circ} 50^{\prime} 15.1^{\prime \prime} \mathrm{W}\right)$, at $2284 \mathrm{~m}$ (S2E1, Millon et al. 1973:106). The profile consists of a partially eroded alluvial soil overlying a highly contrasting flat layer of sand.
Beta-73329

$$
\begin{aligned}
& \text { Ap }(0-20 \mathrm{~cm}) \\
& \text { Ap/AC }(20-40 \\
& 2 \mathrm{C}(40-75 \mathrm{~cm})
\end{aligned}
$$$$
\text { Ap/AC }(20-40 \mathrm{~cm}) \quad 1220 \pm 70
$$

94-8. Located S of San Sebastián Xolalpan, $50 \mathrm{~m} \mathrm{~N}$ of the federal highway $\left(19^{\circ} 40^{\prime} 22^{\prime \prime} \mathrm{N}\right.$, $98^{\circ} 50^{\prime} 50^{\prime \prime} \mathrm{W}$ ), at $2278 \mathrm{~m}$ (S2E1, Millon et al. 1973:106). This polycyclic profile is comprised of 2 soils: the surface is of alluvial origin, poorly developed, with a depth of $37 \mathrm{~cm}$, while the underlying soil shows moderate development.

$\begin{array}{lll} & \text { Ap }(0-25 \mathrm{~cm}) & \\ & \text { AC }(25-37 \mathrm{~cm}) & 1200 \pm 80 \\ \text { Beta-73330 } & \text { C }(37-56 \mathrm{~cm}) & 1590 \pm 70 \\ \text { Beta-73331 } & \text { 2A }(56-100 \mathrm{~cm}) & \\ & \text { 2Bw }(100-170 \mathrm{~cm}) & \end{array}$

99-5. Tlajinga 3 is located $500 \mathrm{~m} \mathrm{~S}$ of Río San Lorenzo $\left(19^{\circ} 39^{\prime} 57^{\prime \prime} \mathrm{N}, 98^{\circ} 50^{\prime} 41^{\prime \prime} \mathrm{W}\right)$, at $2288 \mathrm{~m}$ (S3W1, Millon et al. 1973:114). This polycyclic profile is comprised of 2 moderately developed soils of alluvial origin: the first to a depth of $133 \mathrm{~cm}$, the second to approximately $260 \mathrm{~cm}$. It is situated adjacent to prehispanic agricultural fields with evidence for floodwater irrigation (Nichols 1988; Nichols et al. 1991; Nichols and Frederick 1993). Ceramics associated with the $2 \mathrm{~A}_{11}$ horizon indicate Classic Teotihuacán period occupation (predominantly Tlamimilolpa-phase ceramics, Pérez 2003). No ceramics were recovered from the underlying $2 \mathrm{~A}_{12}$ horizon.

$$
\begin{aligned}
& \mathrm{A}(0-35 \mathrm{~cm}) \\
& \mathrm{B}_{1}(35-95 \mathrm{~cm})
\end{aligned}
$$




$\begin{array}{llr}\text { Beta-142228 } & \mathrm{B}_{2}(95-120 \mathrm{~cm}) & 2890 \pm 50 \\ & \delta^{13} \mathrm{C}=-16.2 & \\ \text { Beta-142229 } & \mathrm{C}(120-133 \mathrm{~cm}) & 3370 \pm 60 \\ & \delta^{13} \mathrm{C}=-16.6 & 2990 \pm 80 \\ \text { Beta-142230 } & 2 \mathrm{~A}_{11} \text { horizon }(133-158 \mathrm{~cm}) & \\ & \delta^{13} \mathrm{C}=-15.7 & 3110 \pm 80 \\ \text { Beta-142231 } & 2 \mathrm{~A}_{12} \text { horizon }(158-171 \mathrm{~cm}) & \\ & \delta^{13} \mathrm{C}=-15.8 & \\ & 2 \mathrm{~B}(171-240 \mathrm{~cm}) & \\ & 2 \mathrm{C}(240-260 \mathrm{~cm}) & \end{array}$

94-2. Located $1.5 \mathrm{~km} \mathrm{NE}$ of Tlacatecpan $\left(19^{\circ} 40^{\prime} 40.3^{\prime \prime} \mathrm{N}, 98^{\circ} 47^{\prime} 48.6^{\prime \prime} \mathrm{W}\right)$, at an elevation of $2318 \mathrm{~m}$. This is a stratified polycyclic profile comprised of 2 weakly developed alluvial soils. Depths indicate short, temporally distant cycles of landscape stability. Beta-73311 compares with Beta-68347 and Beta-68348; see comments on Profile 92-7.

$\begin{array}{llr} & \text { Ap }(0-13 \mathrm{~cm}) & \\ \text { Beta-73308 } & \mathrm{A}_{1}(13-26 \mathrm{~cm}) & 100.1 \pm 0.8 \% \text { Modern } \\ \text { Beta-73309 } & \mathrm{A}_{2}(26-43 \mathrm{~cm}) & 700 \pm 60 \\ \text { Beta-73310 } & \mathrm{C}(43-50 \mathrm{~cm}) & 1430 \pm 70 \\ \text { Beta-73311 } & 2 \mathrm{C} \text { horizon }(>50 \mathrm{~cm}), & 7770 \pm 60 \mathrm{AMS} \\ (\text { CAMS-14619) } & \delta^{13} \mathrm{C}=-16.5 & \end{array}$

94-4. Located $200 \mathrm{~m} \mathrm{NW}$ of a railroad, approximately $500 \mathrm{~m} \mathrm{~S}$ of the barranca Puente el Muerto $\left(19^{\circ} 41^{\prime} 39.6^{\prime \prime} \mathrm{N}, 98^{\circ} 48^{\prime} 28.2^{\prime \prime} \mathrm{W}\right)$, at $2303 \mathrm{~m}$. The profile represents 4 short cycles of soil development, indicated by mineralogical and textural discontinuities.

$\begin{array}{llr}\text { Beta-73313 } & \text { Ap }(0-30 \mathrm{~cm}) & 490 \pm 80 \\ \text { Beta-73314 } & \text { 2AC }(30-55 \mathrm{~cm}) & 2650 \pm 60 \\ & 3 \mathrm{C}(55-64 \mathrm{~cm}) & \\ & 4 \mathrm{C}(>64 \mathrm{~cm}) & \end{array}$

94-5. Located $50 \mathrm{~m} \mathrm{~N}$ of the barranca Puente el Muerto, $400 \mathrm{~m} \mathrm{~S}$ of Barranca del Estete, $1 \mathrm{~km} \mathrm{SW}$ of San Pablo Ixquitlan $\left(19^{\circ} 42^{\prime} 15.5^{\prime \prime} \mathrm{N}, 98^{\circ} 48^{\prime} 04.3^{\prime \prime} \mathrm{W}\right)$, at $2306 \mathrm{~m}$. This polycyclic profile is comprised of 2 moderately developed soils below the surface horizon, the depths of which suggest formation during cycles of relative landscape stability.

$\begin{array}{llr} & \text { Ap }(0-20) & \\ \text { Beta-73315 } & \text { 2Ah }(20-38 \mathrm{~cm}) & 3290 \pm 80 \\ \text { Beta-73316 } & \text { 2'Ah }(38-69 \mathrm{~cm}) & 2030 \pm 60 \\ \text { Beta-73317 } & \text { 2B }(69-83 \mathrm{~cm}) & 1540 \pm 70 \\ \text { Beta-73318 } & 3 \mathrm{~B}_{1}(83-118 \mathrm{~cm}) & 2850 \pm 70 \\ \text { Beta-73319 } & 3 \mathrm{~B}_{2}(118-155 \mathrm{~cm}) & 3420 \pm 80 \\ \text { Beta-73320 } & \text { 3BC }(155-189 \mathrm{~cm}) & 3210 \pm 60 \\ \text { Beta-73321 } & \text { 3C horizon }(189-240 \mathrm{~cm}) & \end{array}$

99-4. Located $100 \mathrm{~m}$ NE of Barranca del Muerto, W of the road between Otumba and San Francisco Tlatica $\left(19^{\circ} 41^{\prime} 33^{\prime \prime} \mathrm{N}, 98^{\circ} 45^{\prime} 46^{\prime \prime} \mathrm{W}\right)$, at $2318 \mathrm{~m}$. This polycyclic profile is comprised of 2 soils of alluvial origin with evidence of stratification. The upper soil with a depth of $86 \mathrm{~cm}$ is poorly developed and contrasts markedly with the underlying fine-textured soil that shows slightly greater development, characterized by the presence of organic-mineral horizons. The profile was situated adjacent 
to archaeological excavations undertaken by Charlton $(1979,1991)$ in remnants of presumed floodwater irrigation canals and fields. Based on analyses by Pérez (2003:106-7), ceramics associated with the $\mathrm{C}_{1}$ and $\mathrm{C}_{2}$ horizons pertain to the Aztec occupation; ceramics associated with the $2 \mathrm{~A}_{11}$ horizon correspond to the Mazapa phase (Toltec). No ceramics were recovered from underlying layers. This profile reflects a period of considerable instability following the abandonment of Teotihuacán (also reported in the Texcoco region, south of the Sierra de Patlachique, by Cordoba [1997]).

$\begin{array}{llll} & \mathrm{Ap}(0-55 \mathrm{~cm}) & & \\ \text { Beta-142221 } & \mathrm{C}_{1} \text { horizon, N wall }(55-75 \mathrm{~cm}) & \delta^{13} \mathrm{C}=-17.0 & 2980 \pm 60 \\ \text { Beta-142225 } & \mathrm{C}_{1} \text { horizon, W wall }(68-76 \mathrm{~cm}) & \delta^{13} \mathrm{C}=-18.3 & 3340 \pm 70 \\ \text { Beta-142222 } & \mathrm{C}_{2} \text { horizon, N wall }(75-86 \mathrm{~cm}) & \delta^{13} \mathrm{C}=-18.3 & 3540 \pm 60 \\ \text { Beta-142223 } & 2 \mathrm{~A}_{11} \text { horizon, N wall }(86-110 \mathrm{~cm}) & \delta^{13} \mathrm{C}=-17.9 & 2890 \pm 60 \\ \text { Beta-142227 } & 2 \mathrm{~A}_{11} \text { horizon, W wall }(90-100 \mathrm{~cm}) & \delta^{13} \mathrm{C}=-19.0 & 3350 \pm 60 \\ \text { Beta-142224 } & 2 \mathrm{~A}_{12} \text { horizon, N wall }(110-137 \mathrm{~cm}) & \delta^{13} \mathrm{C}=-19.3 & 3080 \pm 70 \\ & 2 \mathrm{AC} \mathrm{C}_{1}(137-167 \mathrm{~cm}) & & \\ & 2 \mathrm{AC}_{2}(167-196 \mathrm{~cm}) & & \\ & 2 \mathrm{C}(196-222 \mathrm{~cm}) & & \end{array}$

\section{DISCUSSION}

The interpretation of ${ }^{14} \mathrm{C}$ dates based on organic materials from soils and paleosols is difficult because these materials reflect an "open system" characterized by intensive exchange of carbon with the atmosphere and biota in the course of soil formation together with possible inputs and losses of organic matter after burial. However, the collection of ${ }^{14} \mathrm{C}$ dates from paleosols in the Teotihuacán Valley can be interpreted to elucidate the major periods of landscape stability (development of continuous soil cover) versus periods of intensification of geomorphologic processes (soil erosion on the slopes and sediment accumulation in the valley bottom) which occurred within the last $\sim 10,000 \mathrm{yr}$.

Intensive turnover of the organic matter in the soils (SOM) implies the interpretation of its ${ }^{14} \mathrm{C}$ age as mean residence time (MRT) of C in the soil system (Campbell et al. 1967; Geyh et al. 1971). In general, MRT is rather short in most soils, especially in those formed under temperate and tropical climatic conditions with high rates of biological activity and decomposition (Beckmann and Hubble 1974; Herrera and Tamers 1971; Trumbore 2000). In the Teotihuacán Valley, short MRT is evidenced by relatively recent ${ }^{14} \mathrm{C}$ ages in the majority of contemporary surface A horizons $(0-30 \mathrm{~cm})$, in the range of 100-300 yr (profiles 92-6 and 92-7 from the upland zone; profiles 92-14, 94-6, 94-2 from the alluvial plain). This implies that in buried paleosols the ${ }^{14} \mathrm{C}$ age of humus gives the "minimum age" of pedogenesis, corresponding to the final stages of soil formation, close to the time of the burial event (Matthews 1985). This mode of interpretation is mostly valid for the studied paleosols, being more reliable for mature upland buried Luvisols and Cambisols (which probably have reached the steady state of organic matter, as defined by Wang et al. [1996]) and somewhat limited for the buried underdeveloped Fluvisols of the alluvial plain, which are not likely to reach a steady state.

Furthermore, the paleosols of each geomorphologic zone reflect specific processes of pedogenesis and diagenesis, which also complicates the interpretation of the ${ }^{14} \mathrm{C}$ dates. In most of the profiles of the upland zone, the buried paleosols are very shallow: nearly all dated horizons are located within $2 \mathrm{~m}$ of the present-day land surface, and in some profiles the depth is less than $1 \mathrm{~m}$. In many cases, paleosols are not separated from the modern soil profile by a true $\mathrm{C}$ horizon (without signs of modern pedogenesis); thus, they constitute pedocomplexes. In such an environment, rejuvenation of ${ }^{14} \mathrm{C}$ by means of contamination from younger organic carbon from the contemporary soil system is pos- 
sible through input from the biomass of roots and microorganisms and vertical migration of organic components due to bioturbation and infiltration.

This dilution by recent organic components can be further incremented by partial uncompensated decomposition of the paleosol humus after burial. This diagenetic loss of humus is likely to cause only a minor change of ${ }^{14} \mathrm{C}$ age per se (Matthews 1985). However, it could influence the measurement indirectly in the case of contamination, by increasing the ratio of contaminants with respect to the original organic components of the paleosol.

In case studies of the rejuvenation of organic material in close-to-surface paleosol Ah horizons of Holocene age, the shift of the ${ }^{14} \mathrm{C}$ age was reported to be about 2000 to $3000 \mathrm{yr}$ (Alexandrovskiy and Chichagova 1998; Scharpenseel 1971). A similar shift may apply to the paleosols under consideration, and archaeological evidence in the Teotihuacán Valley partially supports this hypothesis.

\section{Uplands}

Assuming that the ${ }^{14} \mathrm{C}$ date represents the minimal age of paleosol formation, close to the moment of soil burial, together with the high probability of rejuvenation, we interpret the ${ }^{14} \mathrm{C}$ age of the upland paleosols as indicative of a time prior to the soil burial, at least for the upper paleosol horizons. In all profiles, with the exception of 92-6, it exceeds 2000 BP. In the profiles 92-1, 92-2, 92-7, 92-11, 94-9 (lower paleosol B-horizon), and 94-10 (upper paleosol Ah horizon), it lies in the range 3000-8000 BP, and in paleosol B horizons of 94-10 it exceeds 10,000 yr.

We argue that the paleosols of the upland zone are the remains of what was formerly a continuous soil cover, locally preserved under tuffs and destroyed elsewhere by erosion. The formation of this soil cover occurred within an extensive period of landscape and vegetation stability which, according to the ${ }^{14} \mathrm{C}$ dates obtained, took place in the Early-Middle Holocene (well before $\sim 3000 \mathrm{BP}$ ) and probably extended back to the Late Pleistocene. With respect to the latter assumption, it should be mentioned that well-developed paleosols of Late Pleistocene age, including those formed during the Last Glacial Maximum, are reported from various locations in the central Mexican highlands (Solleiro-Rebolledo et al. 1999; Sedov et al. 2001).

\section{Alluvial Plain}

The buried paleosols in the alluvial plain are rather shallow (within $2 \mathrm{~m}$ from modern land surface in the majority of profiles), suggesting their susceptibility to contamination by carbon from the modern surface soil. In addition, the paleosols in this zone were formed from fluvial sediments consisting largely of redeposited soil material from different parts of the valley. Thus, they probably contain older allochthonous organic material mixed with in situ humus formed in the course of pedogenesis, and the inherited organic components from the fluvial parent material could make up a considerable part, especially in the $\mathrm{B}$ and $\mathrm{C}$ horizons.

Rather than corresponding to the minimum soil age/burial event, the ${ }^{14} \mathrm{C}$ dates of the paleosols in the alluvial plain suggest that they are older and closer to (but still younger than) the erosion/sedimentation phase during which the parent material was formed. This inheritance hypothesis enables us to explain various inversions (older ${ }^{14} \mathrm{C}$ ages in the upper horizons) found in many profiles of the alluvial plain and rarely observed in the profiles of the upland zone. This phenomenon seems to depend upon the relation between allochthonous redeposited and in situ pedogenic humus in different parts of the profile and takes place when the upper horizon contains a higher proportion of the allochthonous humus component. 
Most of the alluvial paleosol sequences in the Teotihuacán Valley fall between 4000-1000 BP. We interpret these dates as indicative of the period of intensive soil erosion in the upper parts of the valley and pedosediment deposition in its bottom, which occurred during the Late Holocene (probably after $5000 \mathrm{BP}$ ). In the very bottom of some alluvial sequences, ${ }^{14} \mathrm{C}$ determinations were considerably older than $5000{ }^{14} \mathrm{C}$ BP. These older ages may be indicative of a phase of pedogenesis prior to the period of intensive geomorphologic processes. Judging from their ${ }^{14} \mathrm{C}$ ages, these horizons seem to correspond to the same period of pedogenesis as the paleosols of the upland zone. If this interpretation is correct, then these horizons can be correlated stratigraphically with the upland paleosols and represent the same paleosol cover.

Thus, the interpretation of the ${ }^{14} \mathrm{C}$ data set from the paleosols of the slopes and terraces of the upland zone (representing an Early-Middle Holocene period of landscape stability and continuous pedogenesis) and that of alluvial plain (associated with a Late Holocene period of active erosion/sedimentation) are concordant and complementary.

The proposed correlation among soil profiles is shown in Figure 2. The oldest stages of soil formation found in the uplands (94-10, 92-1, thought to be older than 5000 BP) have no analogs in the alluvial plain. Another stage, probably between 4000 and $2000 \mathrm{BP}$, is recognized in the soils of the alluvial plain and the slopes of Sierra Patlachique. The youngest episode (>500 BP) corresponds to recent historical and present-day processes.

\section{Archaeological Evidence from Soil Profiles}

Although little archaeological data is available which specifically indicates the timing of the processes described here, some elements inadvertently contribute to the development of hypotheses that will benefit from future research. Several horizons provided associated ceramics or remains of structures that were clearly identifiable as corresponding to the Classic period occupation of the urban center of Teotihuacán (about AD 100-650). Ceramic evidence from a single dated horizon in profile 99-4 was clearly related to the Mazapan phase (Toltec occupation, about AD 900-1200). Predominantly Aztec ceramics (about AD 1350-1520) were evident in profile 99-4 in horizons overlying those with ${ }^{14} \mathrm{C}$ determinations. These ceramic materials were likely redeposited during an episode of erosion and do not appear to represent in situ activities. In profile 92-14, a carbonized maize fragment dated to the Aztec period was recovered from sediment that was independently dated. These contexts and the associated ${ }^{14} \mathrm{C}$ determinations are indicated in Table 1 . In general, considerable divergence is evident between the sediment dates and the chronological time when human groups occupied the area.

As yet, we do not have sufficient data to permit a systematic comparison between soil ${ }^{14} \mathrm{C}$ dates and independently dated associated archaeological materials (cf. Alexandrovskiy and Chichagova 1998). However, based on rough estimates, we observe that the ${ }^{14} \mathrm{C}$ determinations of sediments in the alluvial plain tend to fall within a range of approximately 2200-2500 cal yr older than the associated archaeological materials. Sediments directly beneath archaeological structures or burials are even more variable: $\sim 1300 \mathrm{yr}$ in the case of $92-13$ in the alluvial plain, $\sim 2500 \mathrm{yr}$ in $92-2$ and $\sim 4500 \mathrm{yr}$ in $92-1$ in the upland zone.

\section{CONCLUSION}

The study region has witnessed 3 millennia of intense human activity, beginning in the prehispanic period with its settlement by full-time agriculturalists ( 1150 BC, Sanders et al. 1979:201), the expansion of agricultural intensification during the period of the Teotihuacán state's dominance (about AD 100-650), and at the height of the Aztec period through the early Colonial occupation (about AD 1400-1550). 


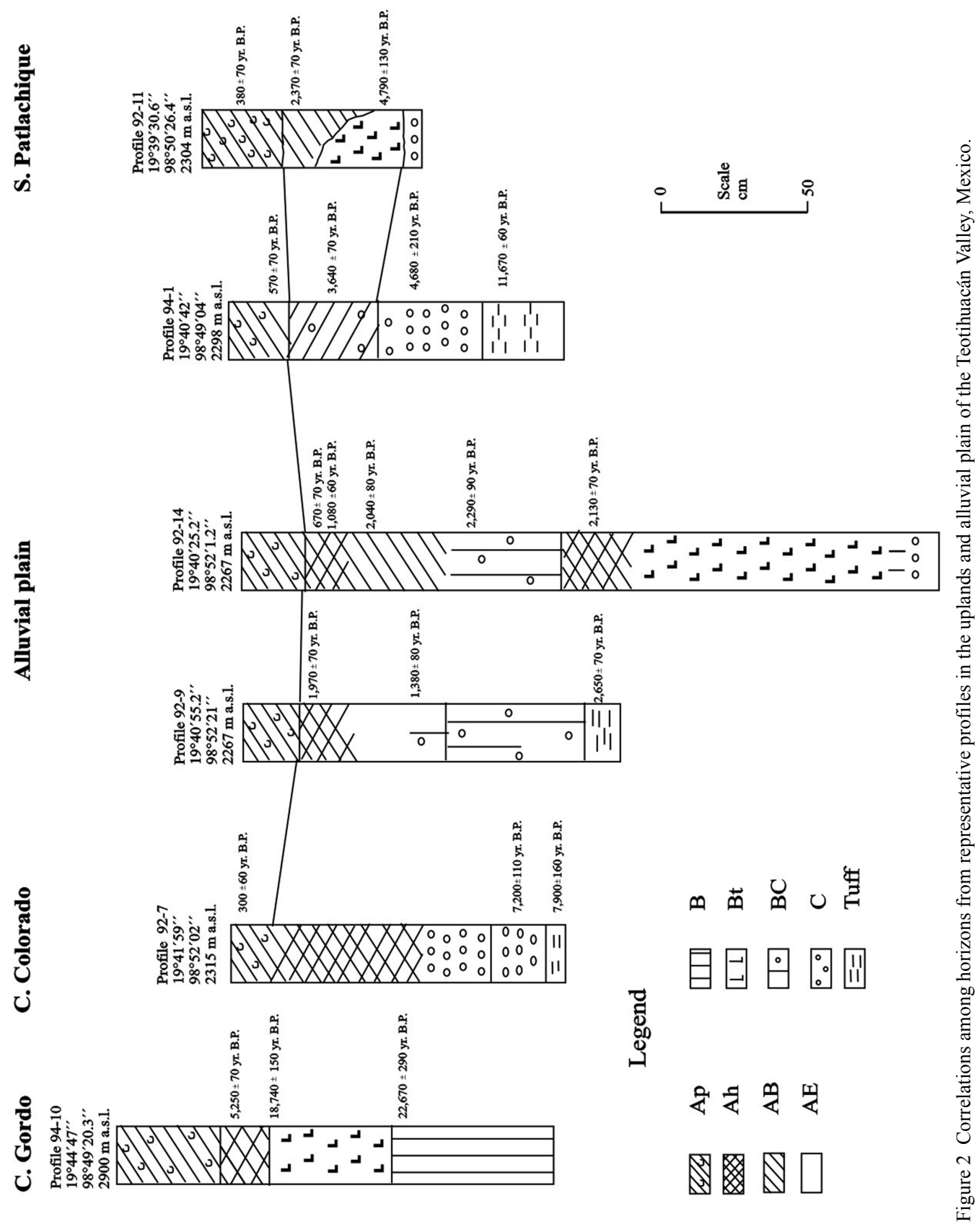


Based on Heine's $(1987,2003)$ and Cordova's (1997) investigations in the adjacent regions of Puebla-Tlaxcala and Texcoco, respectively, a general model for the Teotihuacán region can be posited as a guide for future research in the area. For example, erosion significantly affects the landscape when population growth and related agricultural activities intensify. Both of these regions were depopulated during the period between AD 100-700 (which parallels increased population in Teotihuacán, cf. Parsons 1968; García Cook 1981), during which time erosion/sedimentation is minimal. After the fall of Teotihuacán, between AD 700 until the Colonial period (about AD 1550), population growth resumes in both Puebla and Tlaxcala, with a corresponding intensification of erosionsedimentation.

Considering the importance of the prehispanic urban center and its attraction as a pole of population concentration, particularly during the Classic period, we would expect evidence for landscape instability in the Teotihuacán Valley to be associated with periods of increased population as a result of migration to the city, at the same time when adjacent regions are depopulated and relatively stable as their landscapes gradually recover.

Finally, based on the density of human occupation together with intensive agricultural production, we propose the following sequence for the Teotihuacán region:

1. 5000-2000 BP (about 3500-100 BC; relative stability with short, intermittent episodes of erosion; no significant human activity until $\sim 1150 \mathrm{BC}$ );

2. 2000-1500 BP (about 100 BC-AD 650; erosion-sedimentation, deforestation, and intensive agriculture);

3. 1500-1000 BP (about AD 650-1100; relative stability, depopulation, and partial recovery of the landscape followed by gradual resettlement towards the end of the period);

4. 1000-500 BP (about AD 1100-1550; erosion-sedimentation, deforestation, and intensive agriculture).

Ongoing research in the Teotihuacán region is oriented towards the development of a meaningful chronological sequence within which evidence for vegetation change and climatic conditions can be situated in order to better understand how prehispanic inhabitants used, modified, and degraded the landscape.

\section{ACKNOWLEDGMENTS}

This research was carried out with support from the Consejo Nacional de Ciencia y Tecnología (CONACYT), Mexico, through grants H9106-0060 and 5412-S9411 to Linda Manzanilla and 25074H to Emily McClung de Tapia, and the Dirección General de Asuntos del Personal Académico of the Universidad Nacional Autónoma de México (PAPIIT/DGAPA-UNAM) through grants IN405997 and IN400403 to Emily McClung de Tapia. Additional logistical support for fieldwork was provided by the Instituto de Investigaciones Antropológicas (UNAM), Instituto de Geografía (UNAM), Instituto de Geología (UNAM), and the Departamento del Hombre y su Ambiente, Universidad Autónoma Metropolitana-Xochimilco. We would like to thank J Cervantes, M Meza, G Alfaro, J Zurita, E Ibarra, J L Villalpando, J García, D Martínez, C Adriano, and J Pérez for their assistance in the field at different stages of the research. We also thank Konstantin Pustovoitov for reviewing the draft. The final version of Figure 1 was prepared by Cesar Fernández Amaro. 


\section{REFERENCES}

Alexandrovskiy AL, Chichagova OA. 1998. The ${ }^{14} \mathrm{C}$ age of humic substances in paleosols. Radiocarbon 40(2): 991-7.

Barba LA. 1995. El impacto humano en la paleogeografía de Teotihuacán [PhD dissertation]. Mexico: Facultad de Filosofía y Letras, Universidad Nacional Autonoma de México.

Beckmann GG, Hubble GD. 1974. The significance of radiocarbon measurements of humus from Krasnozems (Ferralsols) in subtropical Australia. Transactions of the 10th International Congress on Soil Science 6: $362-71$.

Caballero M, Lozano S, Ortega B, Urrutia J, Macías JL. 1999. Environmental characteristics of Lake Tecocomulco, northern Basin of Mexico, for the last 50,000 years. Journal of Paleolimnology 22:399-411.

Campbell CA, Paul EA, Rennie DA, McCallum KJ. 1967. Factors affecting the accuracy of the carbon dating method of analysis to soil humus studies. Soil Science 104:81-4.

Cabrera-Castro R. 2002. Nuevas evidencias arqueológicas del manejo de agua en Teotihuacán. El campo y la ciudad. Paper presented at the III Mesa Redonda de Teotihuacán, Centro de Estudios Teotihuacános, Zona Arqueológica de Teotihuacán, Mexico.

Charlton TH. 1979. Investigaciones arqueológicas en el municipio de Otumba, temporada de 1978, $5^{\mathrm{a}}$ parte: el riego y el intercambio: la expansión de Tula [unpublished report submitted to the Consejo de $\mathrm{Ar}$ queología]. Iowa City: University of Iowa.

Charlton TH. 1990. Operation 12, Field 20, irrigation system excavations. Preliminary report on recent research in the Otumba City State. In: Charlton TH, Nichols DL, editors. Mesoamerican Research Report 3. Iowa City: University of Iowa. p 210-2.

Cid JR. 1998. Diacronía y sincronía en el sector oeste de la antigua ciudad de Teotihuacán. In: Brambila $\mathrm{R}, \mathrm{Ca}-$ brera R, coordinators. Los Ritmos de Cambio en Teotihuacán: Reflexiones y Discusiones de su Cronología. Mexico: Instituto Nacional de Antropología e Historia. $\mathrm{p} 317-22$

Cordova C. 1997. Landscape transformation in Aztec and Spanish colonial Texcoco, Mexico [PhD dissertation]. Austin: University of Texas at Austin.

García Cook A. 1981. The historical importance of Tlaxcala in the cultural development of the central highlands. In: Sabloff JA, editor. Supplement to the Handbook of Middle American Indians, V. I. Archaeology. Austin: University of Texas Press. p 244-76.

Geyh MA, Benzler JH, Roeschman G. 1971. Problems of dating Pleistocene and Holocene soils by radiometric methods. In: Yaalon DH, editor. Paleopedology: Origin, Nature and Dating of Paleosols. Jerusalem: International Society of Soil Science and Israel Universities Press. p 63-75.

Heine K. 1987. Anthropogenic sedimentological changes during the Holocene in Mexico and Central America. Striae 26:51-63.

Heine K. 2003. Paleopedological evidence of human-induced environmental change in the Puebla-Talxcala area (Mexico) during the last 3500 years. Revista Mexicana de Ciencias Geológicas 20(3):235-44.

Herrera R, Tamers MA. 1971. Radiocarbon dating of tropical soil associations in Venezuela. In: Yaalon DH, editor. Paleopedology: Origin, Nature and Dating of Paleosols. Jerusalem: International Society of Soil Science and Israel Universities Press. p 109-15.

Hidalgo C. 1996. Étude d'horizons indurés à comportement de fragipan, appelés tepetates, dans les sols volcaniques de la vallée de México. Contribución à la connaissance de leurs caractères et de leur formation [PhD dissertation]. Paris: Université Henri Poincaré, Nancy I, Thèses et documents microfichés nr 146. Orstom éditions.

INEGI. 1983. Texcoco, E14B21 (Topografía), 1:50,000 [map]. Mexico: Instituto Nacional de Estadística, Geografia e Informática.

Kovar A. 1970. The physical and biological environment of the Basin of México. The natural environment, contemporary occupations and 16th-century population of the valley. In: Sanders W, Kovar A, Charlton T, Diehl R. The Teotihuacán Valley Project. V. I. Occasional Papers in Anthropology nr 10. University Park: Pennsylvania State University. p 13-67.

Lozano-García MS, Ortega-Guerrero B. 1998. Late Quaternary environmental changes of the central part of the Basin of México; correlation between Texcoco and Chalco basins. Review of Palaeobotany and Palynology 99:77-93.

Lozano-García MS, Ortega-Guerrero B, CaballeroMiranda M, Urrutia-Fucugauchi J. 1993. Late Pleistocene and Holocene paleoenvironments of Chalco Lake, central México. Quaternary Research 40:33242.

Matthews J. 1985. Radiocarbon dating of surface and buried soils: principles, problems and prospects. In: Richards K, Arlett R, Ellis S, editors. Geomorphology and Soils. London: Allen and Unwin. p 271-88.

McClung de Tapia E. 2000. Prehispanic agricultural systems in the Basin of Mexico. In: Lentz D, editor. Imperfect Balance. Landscape Transformations in the Pre-Columbian Americas. New York: Columbia University Press. p 121-46.

McClung de Tapia E, Solleiro-Rebolledo E, Gama-Castro J, Villalpando JL, Sedov S. 2003. Paleosols in the Teotihuacán Valley, Mexico: evidence for paleoenvironment and human impact. Revista Mexicana de Ciencias Geológicas 20(3):270-82.

Miehlich G. 1991. Chronosequences of volcanic ash soils. Hamburger Bodenkündliche Arbeiten 15. Hamburg.

Millon R, Drewitt B, Cowgill G. 1973. Urbanization at 
Teotihuacán V. I. The Teotihuacán Map. Part 2. Austin: University of Texas Press.

Mooser F. 1968. Geología, naturaleza y desarrollo del Valle de Teotihuacán. In: Lorenzo JL, editor. Materiales par el Estudio de Teotihuacán. Mexico: Instituto Nacional de Antropología e Historia. p 31-38.

Nichols DL. 1988. Infrared aerial photography and prehispanic irrigation at Teotihuacán: the Tlajinga canals. Journal of Field Archaeology 15:17-27.

Nichols DL, Frederick C. 1993. Irrigation canals and chinampas. Recent research in the northern Basin of Mexico. Research in Economic Anthropology (Supplement) 7:123-50.

Nichols DL, Spence M, Borland M. 1991. Watering the fields of Teotihuacán. Early irrigation at the ancient city. Ancient Mesoamerica 2:119-29.

Parsons JR. 1968. Teotihuacán, Mexico, and its impact on regional demography. Science 162:872-7.

Peña D, Zebrowski C. 1992. Estudio de los suelos volcánicos endurecidos (tepetates) de las cuencas de México y Tlaxcala (México). Informe del mapa morfopedológico de la vertiente occidental de la Sierra Nevada. ORSTOM-Paris/Justus Liebig UniversitätGiessen/Colegio de Postgraduados-Montecillo/Universidad Autónoma de Tlaxcala. Comisión des Communautés Européenes. Contrat CCE/ORSTOM nr T52-0212.

Pérez J. 2003. La agricultura en Teotihuacán. Una forma de modificación al paisaje [Master's thesis]. Mexico: Facultad de Filosofía y Letras, Universidad Nacional Autónoma de México.

Quantin P. 1992. Etude des sol volcaniques indurés (tepetates) des bassins de México et Tlaxcala (Mexique).
Rapport scientifique final. Commission des Communautés Européenes, Contrat CEE/ORSTOM no. TS20212.

Sanders W, Parsons J, Santley R. 1979. The Basin of Mexico: Ecological Processes in the Evolution of a Civilization. New York: Academic Press.

Scharpenseel HW. 1971. Radiocarbon dating of soils: problems, troubles, hopes. In: Yaalon DH, editor. $\mathrm{Pa}$ leopedology: Origin, Nature and Dating of Paleosols. Jerusalem: International Society of Soil Science and Israel Universities Press. p 77-88.

Sedov S, Solleiro-Rebolledo E, Gama-Castro JE, Vallejo-Gómez E, González-Velázquez A. 2001. Buried palaeosols of the Nevado de Toluca: an alternative record of Late Quaternary environmental change in central Mexico. Journal of Quaternary Science 16(4): 375-89.

Solleiro-Rebolledo E, Gama-Castro E, Palacios-Mayorga S, Shoba SA, Sedov SN. 1999. Late Pleistocene paleosols of central Mexico: genesis and paleoenvironmental interpretation. Eurasian Soil Science 32(10): 1077-84.

Stuiver M, Reimer PJ. 1993. Extended ${ }^{14} \mathrm{C}$ database and revised CALIB $3.0{ }^{14} \mathrm{C}$ age calibration program. In: Stuiver M, Long A, Kra RS, editors. Calibration 1993. Radiocarbon 35(1):215-30.

Trumbore S. 2000. Age of soil organic matter and soil respiration: radiocarbon constraints on belowground C dynamics. Ecological Applications 10(2):399-411.

Wang Y, Amundson R, Trumbore S. 1996. Radiocarbon dating of soil organic matter. Quaternary Research 45: 282-8. 